\title{
Influence of pressure and temperature on the electrical conductivity of dolomite
}

\author{
Shigeaki Ono ${ }^{1} \cdot K_{\text {Kenji Mibe }}^{2}$
}

Received: 19 March 2015 / Accepted: 5 June 2015 / Published online: 21 June 2015

(C) The Author(s) 2015. This article is published with open access at Springerlink.com

\begin{abstract}
The electrical conductivity of dolomite, $(\mathrm{Mg}$, Ca) $\mathrm{CO}_{3}$, was investigated under conditions of $650-1000 \mathrm{~K}$ and 3-6 GPa with a multi-anvil press and an impedance spectroscopy analyzer with a frequency range of $0.05-$ $10^{6} \mathrm{~Hz}$. As pressure increased, an increase in the electrical conductivity and a decrease in the calculated activation enthalpy were observed. The negative activation volume observed in this study suggests that the hopping of polarons is the dominant mechanism for the electrical conductivity across the pressure and temperature range investigated. This mechanism is the same as that of magnesite, $\mathrm{MgCO}_{3}$, which has the similar structure of dolomite. In contrast, the mechanism of the ionic conduction was reported in aragonite, $\mathrm{CaCO}_{3}$. These results indicate that the mechanism for the electrical conductivity of carbonate minerals varies because of a crystallographic difference between the calcite- and the aragonite-type structure.
\end{abstract}

Keywords Dolomite $\cdot$ Carbonate $\cdot$ Electrical conductivity $\cdot$ High pressures $\cdot$ High temperatures

\section{Introduction}

Carbon is recycled, mainly as carbonates, by means of a subduction process into the deep Earth. The extent of the

Shigeaki Ono

sono@jamstec.go.jp

1 Research and Development Center for Ocean Drilling Science, Japan Agency for Marine-Earth Science and Technology, 2-15 Natsushima-cho, Yokosuka-shi, Kanagawa 237-0061, Japan

2 Earthquake Research Institute, University of Tokyo, 1-1-1 Yayoi, Bunkyo-ku, Tokyo 113-0032, Japan deep mantle cycle that largely depends on the preservation of carbonates during subduction is so far unknown. Carbonates are assumed to be present as accessory phases in the mantle because of the very low solubility of carbon in the mantle minerals (Keppler et al. 2003; Shcheka et al. 2006). Previous experimental studies demonstrate that $\mathrm{Mg}$ - and Ca-bearing carbonates should be stable in mantle conditions (e.g., Biellmann et al. 1993; Dalton and Wood 1995; Molina and Poli 2000; Yaxley and Brey 2004; Ono et al. 2007; Oganov et al. 2008; Merlini et al. 2012). The many findings of crystalline carbonates within kimberlitic diamonds suggest the occurrence of carbonates in the deep mantle (e.g., Meyer and McCallum 1986; Wang et al. 1996; Sobolev et al. 1997; Stachel et al. 2000). Carbonate minerals may enter subduction zones incorporated in altered basaltic crust, overlying marine sediments and underlying mantle lithosphere. The deep subduction of carbonates is evident from geological observations. Coesite- and diamond-bearing ultra-high-pressure metamorphic rocks contain variable amounts of carbonate minerals (e.g., Sobolev and Shatsky 1990; Okay 1993; Dobrzhinetskaya et al. 2006; Korsakov and Hermann 2006; Perraki et al. 2006). Therefore, it is important to investigate the physical properties of carbonate minerals for an understanding of the behavior of carbon in the deep mantle.

Carbonates usually occur as three phases, magnesite, dolomite, and calcite, at the Earth's surface. Calcite transforms into aragonite in the subducted slab. Ordered dolomite, which is stable at ambient temperature, has a $\mathrm{CO}_{3}{ }^{2-}$ planar unit and exhibits a rhombohedral $(R \overline{3})$ symmetry. At high temperatures, disordered dolomite, which is isomorphous $(R \overline{3} c)$ with magnesite and calcite, is stable. It is known that the reaction dolomite $=$ magnesite + aragonite occurs at pressures higher than $\sim 6 \mathrm{GPa}$ and high temperatures in the subducted slab (Liu and Lin 1995; Martinez 
et al. 1996; Sato and Katsura 2001; Luth 2001; Shirasaka et al. 2002; Antao et al. 2004; Buob et al. 2006; Hammouda et al. 2011; Franzolin et al. 2012). Thus, magnesite, dolomite, and aragonite may play an important role in the transportation of carbon in the subducted slab. Recent advances in geophysical observations have allowed mapping of the electrical conductivity of the Earth's mantle interior. Electrical conductivity measurements on carbonates at high pressures and high temperatures can help the estimation of the distribution of carbon in the deep mantle.

Measurements of the electrical conductivity of magnesite and dolomite have been performed at ambient temperature with a piston-cylinder-type high-pressure apparatus (e.g., Papathannassiou and Grammatikakis 1996; Papathannassiou 1998). The electrical conductivities of calcite and aragonite have been measured at high temperatures and pressures of 2.5-3.5 GPa (Bagdassarov and Slutskii 2003; Heege and Renner 2007). The effects of pressure and temperature on magnesite and aragonite have been reported with a multi-anvil-type high-pressure apparatus up to $1000 \mathrm{~K}$ and $6 \mathrm{GPa}$ (Mibe and Ono 2011; Ono and Mibe 2013). Although previous studies have investigated the electrical conductivity of carbonate minerals, the effect of pressure and temperature in dolomite is still an open question. In this study, we determined the electrical conductivity of dolomite up to $6 \mathrm{GPa}$ and $1000 \mathrm{~K}$ using in situ complex impedance spectroscopy in a multi-anvil high-pressure apparatus.

\section{Experimental procedure}

The starting material was dolomite $\left(\mathrm{Mg}_{0.48} \mathrm{Ca}_{0.52} \mathrm{CO}_{3}\right)$, synthesized from a starting mixture composed of finely powdered $\mathrm{MgCO}_{3}$ and $\mathrm{CaCO}_{3}$. The mixture was heated at $1.2 \mathrm{GPa}$ and $1273 \mathrm{~K}$ for $2.0 \mathrm{~h}$ with a piston-cylindertype high-pressure apparatus. Powder X-ray diffraction measurements were performed on the synthesized sample to confirm the two carbonates reacted to form dolomite. The powder X-ray diffraction pattern of ordered dolomite $(R \overline{3})$ has some additional lines, such as (101), (015), and (021), compared with that of fully disordered dolomite $(R \overline{3} c)$. These lines of the synthesized dolomite were confirmed. Although the degree of ordering could not be estimated because of poor quality of X-ray diffraction data, the appearances of the additional lines indicated that the starting material was ordered dolomite. The chemical composition of the synthesized dolomite was analyzed by electron microprobe analysis. The starting material was dried at $383 \mathrm{~K}$ to minimize the effect of any adsorbed water on the electrical conductivity measurements. In this study, a conventional multi-anvil high-pressure apparatus was used comprising a pressure cell consisting of a $12-\mathrm{mm}$ edge length $\mathrm{Cr}$-doped $\mathrm{MgO}$ octahedron as the confining medium and a graphite sleeve heater (Mibe and Ono 2011). The graphite heater in the cell was connected to the guide blocks of the multi-anvil high-pressure apparatus by Mo electrodes. The cell assembly was kept at $383 \mathrm{~K}$ in an oven and was removed just before the compression experiments began. The experiments were performed at pressures up to $6 \mathrm{GPa}$ and temperatures up to $1000 \mathrm{~K}$. The sample temperature was measured with a $\mathrm{Pt}-\mathrm{Pt}_{87} \mathrm{Rh}_{13}$ thermocouple (Type-R), whose junction was placed outside the Mo electrode. No correction was made for the effect of pressure on the thermocouple emf. Typical temperature fluctuation during heating was within $\pm 5 \mathrm{~K}$. Alumina was used as an insulator between the electrical resistivity measurement lines and the heater lines. The resistivity of alumina used in this study was sufficiently higher than that of the sample at high pressures and high temperatures (Reynard et al. 2011).

Pressure calibration of the cell was carried out with standard calibration point materials: at room temperature for the Bi I-II transformation at $2.55 \mathrm{GPa}$, and at high temperatures for transformations of $\mathrm{SiO}_{2}$, quartz-coesite (Bose and Ganguly 1995) and $\mathrm{Fe}_{2} \mathrm{SiO}_{4}, \alpha-\gamma$ (Ono et al. 2013). The uncertainty in pressure was typically within $10 \%$. The details of the high-pressure experiments have been described elsewhere (Mibe et al. 2003). The complex impedance was measured with a Solartron 1260 Impedance/Gain-Phase Analyzer with a 1296 Dielectric Interface over a frequency range of $0.05 \mathrm{~Hz}-1 \mathrm{MHz}$. The samples were sandwiched between Mo disks in the center of the cell and were connected to the impedance analyzer through Pt$\mathrm{Pt}_{87} \mathrm{Rh}_{13}$ wires (Mibe and Ono 2011). In our experiments, the load was applied to the sample by compressing it to a set oil pressure in the high-pressure apparatus. The sample was then slowly heated until it reached the desired temperature $(1000 \mathrm{~K})$ at a given oil pressure. After reaching the required temperature, the sample was annealed for $30 \mathrm{~min}$, and measurements were taken after the annealing stage. The impedance data of the samples were acquired at temperatures in the range of $650-1000 \mathrm{~K}$ at each $50 \mathrm{~K}$ interval. The recovered samples were polished to measure the distance between the electrodes in the conductivity measurements. Electron microprobe analysis was performed on the recovered samples to confirm that dolomite was stable in measurements of the electrical conductivity of the samples. To check the crystal structure of recovered carbonates, the samples were also examined with micro-Raman spectroscopy (Fig. 1). Raman scattering was excited with the $333 \mathrm{~nm}$ line of a $\mathrm{HeCd}$ laser, and the focused laser spot had a diameter $<10 \mu \mathrm{m}$. 


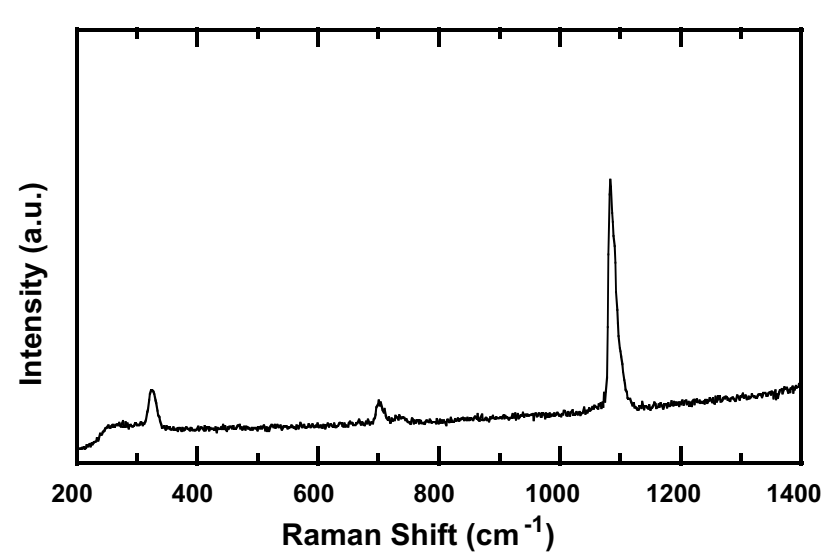

Fig. 1 Raman spectrum of the recovered sample from $6 \mathrm{GPa}$. All peaks are attributed to dolomite

\section{Results}

The measurements of the electrical conductivity were performed at pressures $\leq 6 \mathrm{GPa}$, because dolomite decomposes into magnesite and aragonite at high pressures (Liu and Lin 1995; Martinez et al. 1996; Sato and Katsura 2001; Luth 2001; Shirasaka et al. 2002; Buob et al. 2006). Figure 2 shows a representative complex impedance curve from a sample of dolomite. The real $\left(Z^{\prime}\right)$ and the imaginary $\left(Z^{\prime \prime}\right)$ parts of the impedance spectra were obtained from the measured amplitude $|\mathrm{Z}|$ and the value of $\varphi$ determined at a given frequency, by means of the following equations: $Z^{\prime}=|Z| \cos \varphi$ and $Z^{\prime \prime}=|Z| \sin \varphi$. The arc diameter, which gives the value of the electrical resistance, increased with decreasing temperature. In the temperature and frequency range studied, the samples only showed a simple arc, and so only a resistance-capacitance circuit was required to fit each curve. The fitting errors were $<5 \%$ for each conductivity measurement at a given temperature. The electrical conductivity of samples was calculated with the following equation: $\sigma=\frac{1}{\rho}=\frac{L}{R S}$ where $L, R, S$, and $\rho$ are the sample length $(\mathrm{m})$, resistance of the sample $(\Omega)$, cross-sectional area of the electrode $\left(\mathrm{m}^{2}\right)$, and resistivity of the sample $(\Omega \mathrm{m})$, respectively. The calculated conductivity was fitted to an Arrhenius equation:

$\sigma=\sigma_{0} \mathrm{e}^{-\frac{\Delta H}{k T}}$

$\Delta H=\Delta U+P \Delta V$

where $\sigma$ is the calculated conductivity $(\mathrm{S} / \mathrm{m}), \sigma_{0}$ is the preexponential factor, $\Delta H$ is the activation enthalpy $(\mathrm{eV}), k$ is the Boltzmann constant, and $T$ is the temperature $(\mathrm{K})$. The activation enthalpy is given by Eq. (2), where $\Delta U$ is the activation energy, $P$ is the pressure, and $\Delta V$ is the

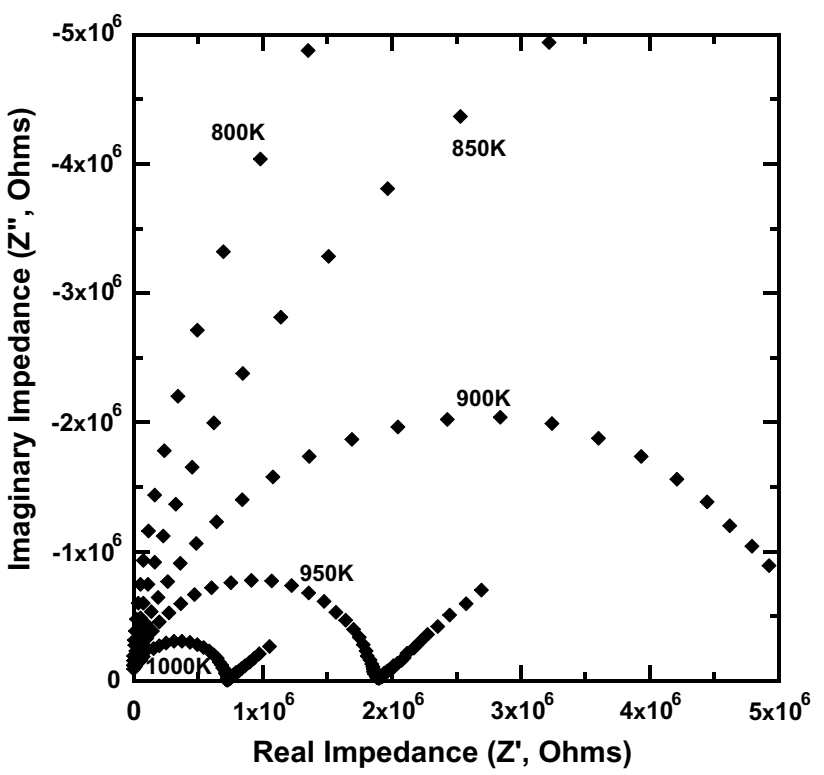

Fig. 2 Complex impedance spectra of dolomite. The solid diamonds denote the values of the real versus the imaginary components of the complex impedance in the frequency range $0.05 \mathrm{~Hz}-1 \mathrm{MHz}$ at temperatures of $800-1000 \mathrm{~K}$ at $3 \mathrm{GPa}$

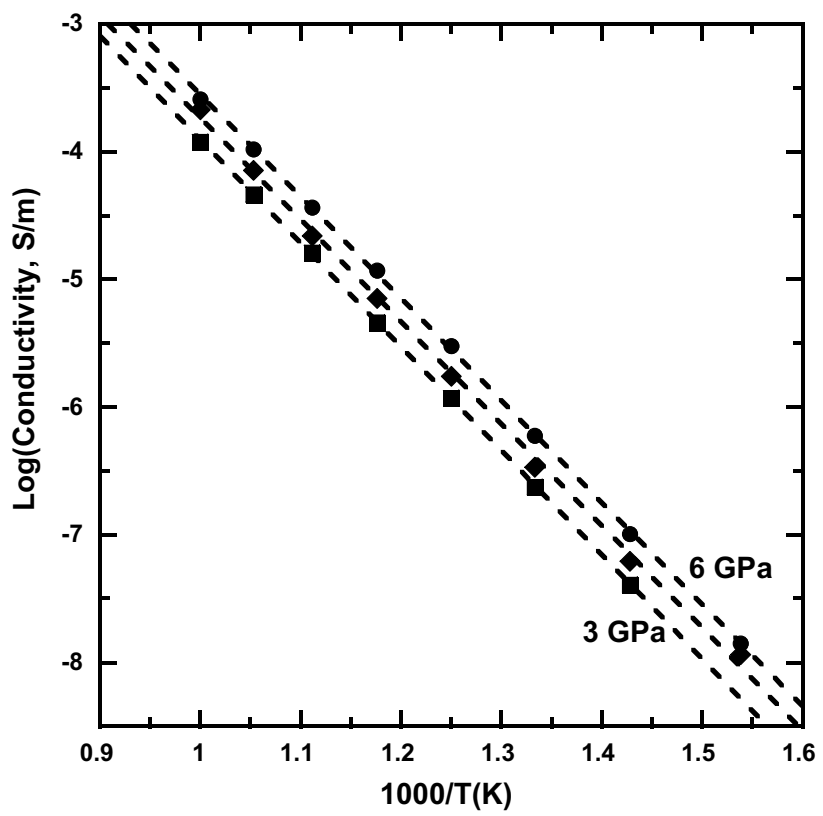

Fig. 3 Electrical conductivity of dolomite plotted as a function of the reciprocal of the temperature $\left(\mathrm{K}^{-1}\right)$. The solid squares, diamonds, and circles denote data at 3.0, 4.5, and $6.0 \mathrm{GPa}$, respectively. The dashed lines represent linear fits to the data

activation volume. In this study, the temperature range was $650-1000 \mathrm{~K}$ and the pressure range was between 3 and $6 \mathrm{GPa}$. 
Table 1 Measurements for dolomite

\begin{tabular}{lllll}
\hline Experiment & $P(\mathrm{GPa})$ & $T$ range $(\mathrm{K})$ & $\sigma_{0}(\mathrm{~S} / \mathrm{m})$ & $\Delta H(\mathrm{eV})$ \\
\hline Dol_4 & 4.5 & $650-1000$ & $1.75 \times 10^{4}(54)$ & $1.58(3)$ \\
Dol_5 & 3.0 & $700-1000$ & $1.65 \times 10^{4}(15)$ & $1.61(1)$ \\
Dol_6 & 6.0 & $650-1000$ & $2.56 \times 10^{4}(33)$ & $1.58(1)$ \\
\hline
\end{tabular}

The results are fitted to the following equation $\sigma=\sigma_{0} \mathrm{e}^{-\frac{\Delta H}{k T}}$. $1 \mathrm{eV}=96.4856 \mathrm{~kJ} / \mathrm{mol}$

Figure 3 shows a graph of the logarithm of the electrical conductivity versus the reciprocal of the temperature for the dolomite samples. Since these data showed one linear response over the experimental temperature range, there is only one conduction mechanism for dolomite. The measured values were fitted to obtain the parameters shown in Eq. (1). Table 1 shows the results of the fitted parameters for each run. A small effect of pressure was observed in the temperature range investigated in our experiments. The change in activation enthalpy in the range of 3-6 GPa was small. The fitted parameters in Table 1 were used to obtain the parameters determining the effect of pressure with Eq. (2). The calculated activation energy and volume were $1.64 \mathrm{eV}$ and $-1.00 \mathrm{~cm}^{3} / \mathrm{mol}$, respectively (Table 2).

\section{Discussion}

Figure 4 shows a comparison of the change in the activation enthalpies in carbonate minerals. The activation enthalpies of dolomite and magnesite decrease as pressure increases. In contrast, that of aragonite increases as pressure increases. According to Eq. (2), a difference in pressure effect is owed to a difference in the activation volume. It is known that the activation volume is related to the electrical conduction mechanism (Lazarus and Nachtrieb 1963; Samara 1984). In the case when extrinsic ionic conduction is the dominant mechanism of the electric conductivity, then a diffusive ion in the saddle-point position expands in the interstitial space and displaces the surrounding ions. In this case, it is expected that the activation volume would have a positive value in the order of several to several tens of $\mathrm{cm}^{3} / \mathrm{mol}$ (e.g., Samara 1984). In contrast, the negative activation volume observed in this study would be expected for minerals with a hopping conduction mechanism (Goddat et al. 1999). If the system has aliovalent impurities, such as iron-bearing silicates, then the conductivity of minerals with a negative activation volume can be attributed to the hopping of small polarons. The activation energy was in the range between the measured value of the activation energy for the chemical diffusion of the Ca cation in magnesite $(2.22 \mathrm{eV})$ and that for the chemical diffusion of $\mathrm{Mg}$ in calcite $(0.79 \mathrm{eV})$ (Kent et al. 2001). The activation
Table 2 Parameters for carbonates

\begin{tabular}{lll}
\hline & $\Delta U(\mathrm{eV})$ & $\Delta V\left(\mathrm{~cm}^{3} / \mathrm{mol}\right)$ \\
\hline Dolomite, $\mathrm{Mg}_{0.48} \mathrm{Ca}_{0.52} \mathrm{CO}_{3}$ & 1.64 & -1.00 \\
Magnesite, $\mathrm{MgCO}_{3}$ & 1.76 & -3.95 \\
Aragonite, $\mathrm{CaCO}_{3}$ & 0.40 & 9.28 \\
\hline
\end{tabular}

The activation enthalpy in the Arrhenius equation is given by the following equation $\Delta H=\Delta U+P \Delta V$, where $\Delta U$ is the activation energy, $P$ is the pressure, and $\Delta V$ is the activation volume

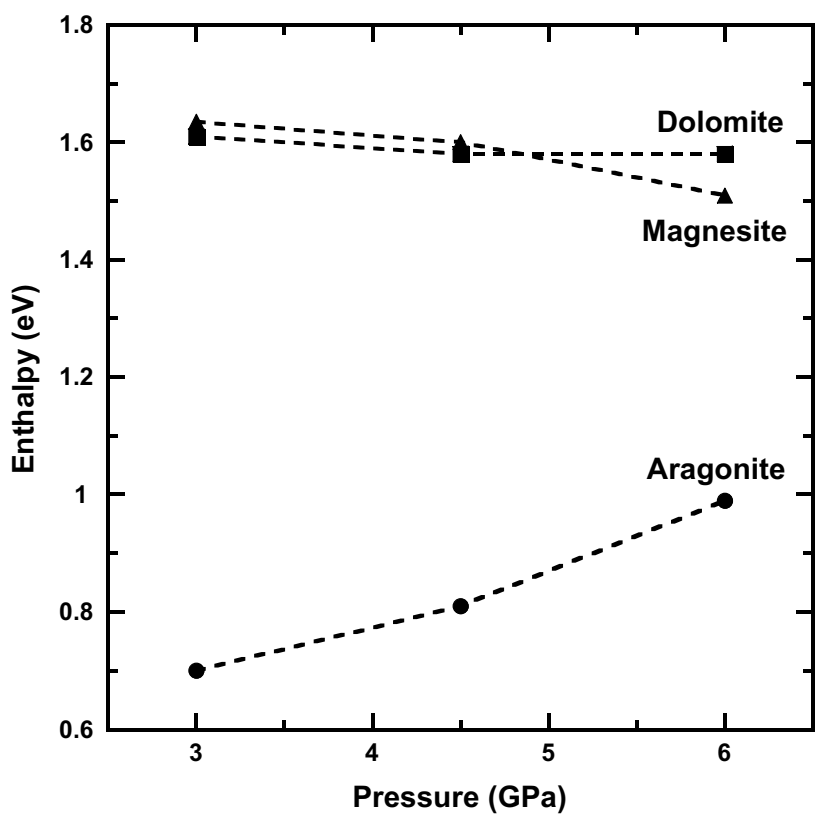

Fig. 4 Comparison of pressure dependence of carbonates. The solid triangles, circles, and squares denote the enthalpy parameters $(\Delta H)$ of magnesite (Mibe and Ono 2011), aragonite (Ono and Mibe 2013), and dolomite (this study) in equation $\sigma=\sigma_{0} \mathrm{e}^{-\frac{\Delta H}{k T}}$

volume of $-1.00 \mathrm{~cm}^{3} / \mathrm{mol}$ calculated in this study supports the idea that dolomite exhibits hopping conduction at high pressures and high temperatures.

Figure 5 shows the activation volumes of carbonates as a function of $\mathrm{Mg} / \mathrm{Ca}$ ratio at pressures of 3-6 $\mathrm{GPa}$. A significant change in the activation volume, which corresponded to a change in the conduction mechanism, was confirmed between dolomite and aragonite. The key to understanding this feature is a change in the crystal structure of carbonate. Magnesite and disordered dolomite have an $R \overline{3} c$ space group, which is the same as that of calcite. In our experimental conditions $(\leq 1000 \mathrm{~K}), \mathrm{Mg}$ and $\mathrm{Ca}$ in dolomite still were ordered, because a critical temperature of ordering was $1343 \pm 20 \mathrm{~K}$ at 3-4 GPa (Antao et al. 2004; Hammouda et al. 2011). As the structure of ordered dolomite synthesized in this study is similar to those of magnesite and calcite, the conduction mechanism 


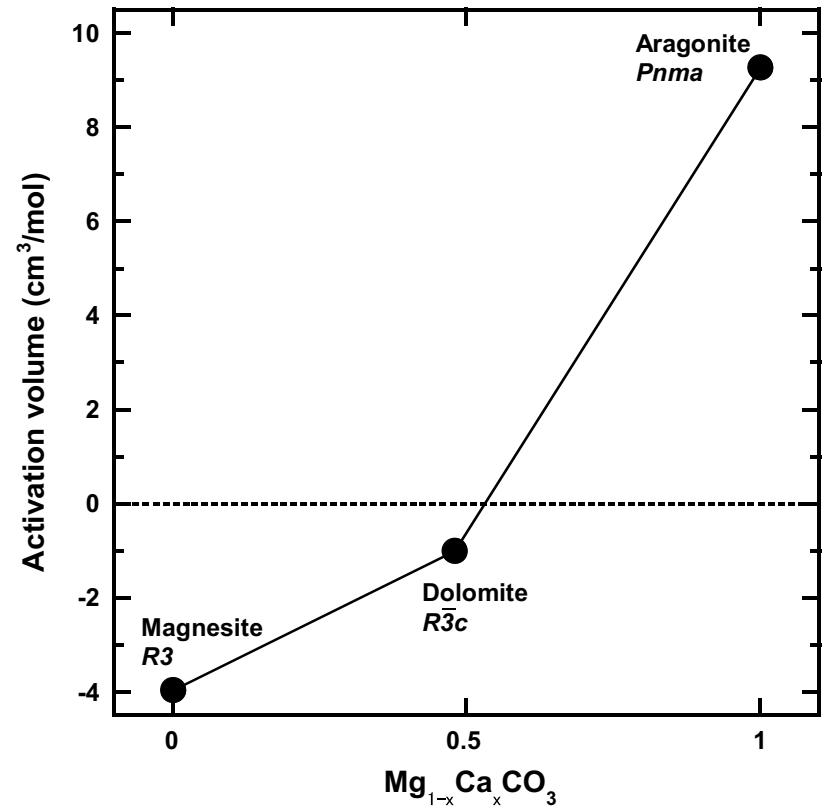

Fig. 5 Comparison of compositional dependence of activation volume in carbonates. The solid circles denotes the activation volume $(\Delta V)$ of magnesite (Mibe and Ono 2011), aragonite (Ono and Mibe 2013), and dolomite (this study) in the equation $\Delta H=\Delta U+P \Delta V$

in dolomite is expected to be similar to that in magnesite and dolomite. In the case of $\mathrm{CaCO}_{3}$ composition, calcite, whose space group is $R \overline{3} c$, transforms to aragonite, whose space group is Pnma, as pressure increases at high temperatures corresponding to the mantle conditions. The difference between two structures is the rotation angle of the $\mathrm{CO}_{3}{ }^{2-}$ units and a small displacement of the position of the cations. This structural difference and the displacement of the ions induce a change in the coordination environment of the $\mathrm{Ca}^{2+}$ cations from sixfold to ninefold. This change in the crystal structure may induce the change in the conduction mechanism. The theoretical model should be investigated in future works. As dolomite decomposes into magnesite and aragonite at around $6 \mathrm{GPa}$, the electrical conductivities of carbonate rocks are controlled by magnesite and aragonite. Magnesite and aragonite are stable up to $80 \mathrm{GPa}$ (Oganov et al. 2008; Fiquet et al. 2002) and up to $40 \mathrm{GPa}$ (Ono et al. 2005), respectively. Therefore, the electrical conductivities of these two carbonates are important for interpreting anomalies in the electrical conductivity observed in the upper mantle.

Figure 6 shows a comparison of the electrical conductivities of carbonates and olivine. It is known that olivine is a major mineral present in the upper mantle, and so its electrical conductivity represents an average value of the upper mantle. The conduction mechanism in olivine is still debated. A discrepancy in the activation volume of olivine was reported by previous studies (Xu et al. 2000; Sakamoto

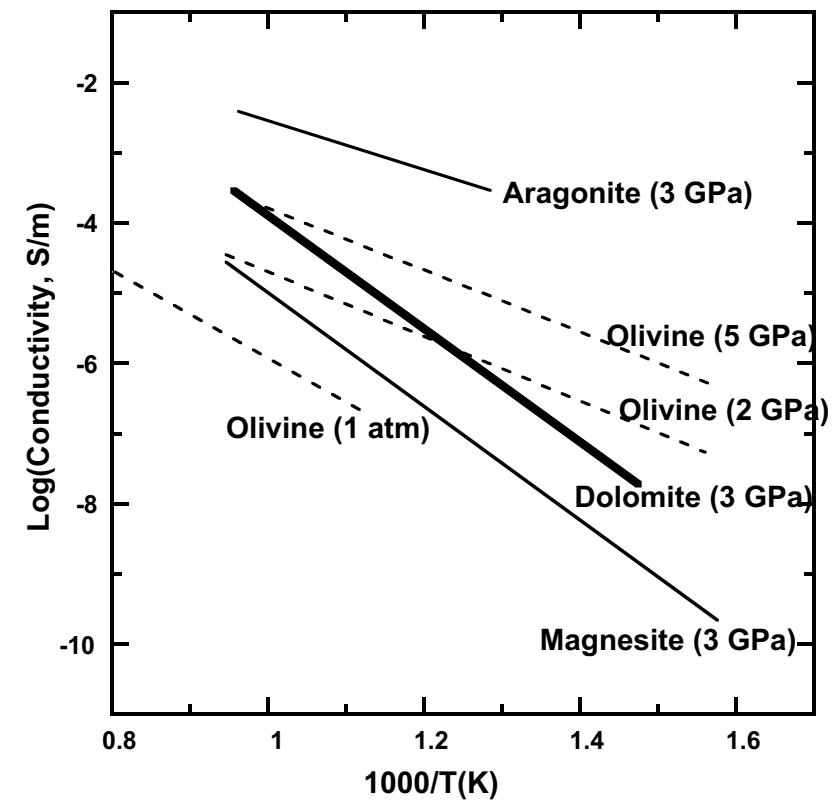

Fig. 6 A comparison of the electrical conductivity of carbonates and olivine. Dolomite, $3 \mathrm{GPa}$ in this study; aragonite, $3 \mathrm{GPa}$ (Ono and Mibe 2013); magnesite, $3 \mathrm{GPa}$ (Mibe and Ono 2011); and olivine, 1 atm (Constable 2006), 2 and 5 GPa from the San Carlos olivine (Sakamoto et al. 2002)

et al. 2002). However, there is no significant inconsistency in the absolute value of the electrical conductivity of olivine at high pressures and high temperatures. The electrical conductivity of dolomite was of the same order of magnitude as that of olivine. Therefore, it is difficult to identify the dolomite-dominated rock bodies in the upper mantle from the perspective of electrical conductivity. In contrast, the electrical conductivity of aragonite was one to two orders of magnitude higher than that of olivine. When the calcium-dominated carbonate rocks, such as marine sediments, in the subducted slabs are dragged into the deep mantle, the electrical conductivity of the aragonitedominated rock bodies is higher than that of the surrounding rocks in the upper mantle. It is known that the electrical conductivity of wet rock, which contains a hydroxyl ion component in its minerals and/or a fluid phase, is higher than that of dry mineral (e.g., Wang et al. 2006; Yoshino et al. 2009; Yang et al. 2011). The calcium carbonates could contribute to the higher electrical conductivity in the same way as the water effect.

\section{Conclusion}

Experimental measurements on synthetic dolomite showed that electrical conductivity increased as pressure increased for the range of 3-6 GPa. The activation volume has the 
negative value which indicates that the hopping of polarons is the dominant mechanism for the electrical conductivity. This electrical property of dolomite is the same as that of magnesite, which crystal structure is similar to that of dolomite. Our direct measurements of dolomite at high pressures and temperatures allow improving the estimation of the electrical conductivity of carbonates in the subducted slab.

Acknowledgments This work was partially supported by JSPS KAKENHI Grant Number 22340131 and the Earthquake Research Institute cooperative research program, Japan.

Open Access This article is distributed under the terms of the Creative Commons Attribution 4.0 International License (http://creativecommons.org/licenses/by/4.0/), which permits unrestricted use, distribution, and reproduction in any medium, provided you give appropriate credit to the original author(s) and the source, provide a link to the Creative Commons license, and indicate if changes were made.

\section{References}

Antao SM, Mulder WH, Hassan I, Crichton WA, Parise JB (2004) Cation disorder in dolomite, $\mathrm{CaMg}(\mathrm{CO} 3)_{2}$, and its influence on the aragonite + magnesite $\leftrightarrow$ dolomite reaction boundary. Am Mineral 89:1142-1147

Bagdassarov NS, Slutskii AB (2003) Phase transformations in calcite from electrical impedance measurements. Phase Trans 76:1015-1028

Biellmann C, Gillet P, Guyot F, Peyronneau J, Reynard B (1993) Experimental evidence for carbonate stability in the Earth's lower mantle. Earth Planet Sci Lett 118:31-41

Bose K, Ganguly J (1995) Quartz-coesite transition revisited: reversed experimental determination at $500-1200{ }^{\circ} \mathrm{C}$ and retrieved thermochemical properties. Am Mineral 80:231-238

Buob A, Luth RW, Schmidt MW, Ulmer P (2006) Experiments on $\mathrm{CaCO}_{3}-\mathrm{MgCO}_{3}$ solid solutions at high pressure and temperature. Am Mineral 91:435-440

Constable S (2006) SEO3: a new model of olivine electrical conductivity. Geophys J Int 166:435-437

Dalton JA, Wood BJ (1995) The stability of carbonate under uppermantle conditions as a function of temperature and oxygen fugacity. Eur J Mineral 7:883-891

Dobrzhinetskaya LF, Wirth R, Green HW (2006) Nanometric inclusions of carbonates in Kokchetav diamonds from Kazakhstan: a new constraint for the depth of metamorphic diamond crystallization. Earth Planet Sci Lett 243:85-93

Fiquet G, Guyot F, Kunz M, Matas J, Andrault D, Hanfland M (2002) Structural refinements of magnesite at very high pressure. Am Mineral 87:1261-1265

Franzolin E, Merlini M, Poli S, Schmidt MW (2012) The temperature and compositional dependence of disordering in Fe-bearing dolomites. Am Mineral 97:1676-1684

Goddat A, Peyronneau F, Poirier JP (1999) Dependence on pressure of conduction by hopping of small polarons in minerals of the Earth's lower mantle. Phys Chem Miner 27:81-87

Hammouda T, Andrault D, Koga K, Katsura T, Martin AM (2011) Ordering in double carbonates and implications for processes at subduction zones. Contrib Mineral Petrol 161:439-450

Heege JHT, Renner J (2007) In situ impedance spectroscopy on pyrophyllite and $\mathrm{CaCO}_{3}$ at high pressure and temperature: phase transformations and kinetics of atomistic transport. Phys Chem Miner 34:445-465

Kent AJ, Hutcheon ID, Ryerson FJ, Phinney DL (2001) The temperature of formation of carbonate in martian meteorite ALH84001: constraints from cation diffusion. Geochim Cosmochim Acta 65:311-321

Keppler H, Wiedenbeck M, Shcheka SS (2003) Carbon solubility in olivine and the mode of carbon storage in the Earth's mantle. Nature 424:414-416

Korsakov AV, Hermann J (2006) Silicate and carbonate melt inclusions associated with diamonds in deeply subducted carbonate rocks. Earth Planet Sci Lett 241:104-118

Lazarus D, Nachtrieb NH (1963) Effect of high pressure on diffusion. In: Paul W, Warchauer DM (eds) Solids under pressure. McGraw-Hill, New York, pp 43-69

Liu L-G, Lin C-C (1995) High-pressure phase transformations of carbonates in the system $\mathrm{CaO}-\mathrm{MgO}-\mathrm{SiO}_{2}-\mathrm{CO}_{2}$. Earth Planet Sci Lett 134:297-305

Luth RW (2001) Experimental determination of the reaction aragonite + magnesite $=$ dolomite at 5 to $9 \mathrm{GPa}$. Contrib Mineral Petrol 141:222-232

Martinez I, Zhang J, Reeder RJ (1996) In situ X-ray diffraction of aragonite and dolomite at high pressure and high temperature: evidence for dolomite breakdown to aragonite and magnesite. Am Mineral 81:611-624

Merlini M, Hanfland M, Crichton WA (2012) $\mathrm{CaCO}_{3}-\mathrm{III}$ andCaCO${ }_{3}$-VI, high-pressure polymorphs of calcite: possible host structures for carbon in the Earth's mantle. Earth Planet Sci Lett 333-334:265-271

Meyer HOA, McCallum ME (1986) Mineral inclusions in diamonds from the Sloan kimberlites. Colorado J Geol 94:600-612

Mibe K, Ono S (2011) Electrical conductivity of $\mathrm{MgCO}_{3}$ at high pressures and high temperatures. Phys B 406:2018-2020

Mibe K, Yoshino T, Ono S, Yasuda A, Fujii T (2003) Connectivity of aqueous fluid in eclogite and its implications for fluid migration in the Earth's interior. J Geophys Res 108:2295

Molina JF, Poli S (2000) Carbonate stability and fluid composition in subducted oceanic crust: an experimental study on $\mathrm{H}_{2} \mathrm{O}-\mathrm{CO}_{2}-$ bearing basalts. Earth Planet Sci Lett 176:295-310

Oganov AR, Ono S, Ma Y, Glass CW, Garcia A (2008) Novel Phases of $\mathrm{MgCO}_{3}, \mathrm{CaCO}_{3}$ and $\mathrm{CO}_{2}$ and their role in the Earth's mantle. Earth Planet Sci Lett 273:38-47

Okay AI (1993) Petrology of a diamond and coesite-bearing metamorphic terrain: Dabie Shan, China. Eur J Mineral 5:659-675

Ono S, Mibe K (2013) Electrical conductivity of aragonite in the subducted slab. Eur J Mineral 25:11-15

Ono S, Kikegawa T, Ohishi Y, Tsuchiya J (2005) Post-aragonite phase transformation in $\mathrm{CaCO}_{3}$ at $40 \mathrm{GPa}$. Am Mineral 90:667-671

Ono S, Kikegawa T, Ohishi Y (2007) High-pressure transition of $\mathrm{CaCO}_{3}$. Am Mineral 92:1246-1249

Ono S, Kikegawa T, Higo Y (2013) In situ observation of a phase transition in $\mathrm{Fe}_{2} \mathrm{SiO}_{4}$ at high pressure and high temperature. Phys Chem Miner 40:811-816

Papathannassiou AN (1998) Effect of hydrostatic pressure on the electrical conductance of dolomite $\left[\mathrm{CaMg}\left(\mathrm{CO}_{3}\right)_{2}\right]$. Phys Rev B 58:4432-4437

Papathannassiou AN, Grammatikakis J (1996) Pressure variation of the electrical conductivity of polycrystalline magnesite $\left(\mathrm{MgCO}_{3}\right)$. Phys Rev B 53:16247-16251

Perraki M, Proyer A, Mposkos E, Kaindi R, Hoinkes G (2006) Raman micro-spectroscopy on diamond, graphite and other carbon polymorphs from the ultrahigh-pressure metamorphic Kimi Complex of the Rhodope Metamorphic Province, NE Greece. Earth Planet Sci Lett 31:672-685

Reynard B, Mibe K, van de Moortèle B (2011) Electrical conductivity of the serpentinised mantle and fluid flow in subduction zones. Earth Planet Sci Lett 307:387-394 
Sakamoto D, Yoshida A, Yamanaka T, Ohtaka O, Ota K (2002) Electric conductivity of olivine under pressure investigated using impedance spectroscopy. J Phys Condens Matter 14:11375-11379

Samara GA (1984) High-pressure studies of ionic conductivity in solids. Solid State Phys 38:1-80

Sato K, Katsura T (2001) Experimental investigation on dolomite dissociation into aragonite + magnesite up to $8.5 \mathrm{GPa}$. Earth Planet Sci Lett 184:529-534

Shcheka SS, Wiedenbeck M, Frost DJ, Keppler H (2006) Carbon solubility in mantle minerals. Earth Planet Sci Lett 245:730-742

Shirasaka M, Takahashi E, Nishihara Y, Matsukage K, Kinegawa T (2002) In situ X-ray observation of the reaction dolomite $=$ aragonite + magnesite at 900-1300 K. Am Mineral 87:922-930

Sobolev NV, Shatsky VS (1990) Diamond inclusions in garnets from metamorphic rocks: a new environment for diamond formation. Nature 343:742-746

Sobolev NV, Kaminsky FV, Griffin WL, Yefimova ES, Win TT, Ryan CG, Botkunov AI (1997) Mineral inclusions in diamonds from the Sputnik kimberlite pipe, Yakutia. Lithos 39:135-157

Stachel T, Harris JW, Brey GP, Joswig W (2000) Kankan diamonds (Guinea) II: lower mantle inclusion parageneses. Contrib Mineral Petrol 140:16-27
Wang A, Pasteris JD, Meyer HOA, DeleDuboi ML (1996) Magnesitebearing inclusion assemblage in natural diamond. Earth Planet Sci Lett 141:293-306

Wang D, Mookherjee M, Xu Y, Karato S (2006) The effect of water on the electrical conductivity of olivine. Nature 443:977-980

Xu Y, Shankland TJ, Duba AG (2000) Pressure effect on electrical conductivity of mantle olivine. Phys Earth Planet Inter 118:149-161

Yang X, Keppler H, MaCammon C, Ni H, Xia Q, Fan Q (2011) The effect of water on the electrical conductivity of lower crustal clinopyroxene. J Geophys Res 113:B08207

Yaxley GM, Brey GP (2004) Phase relations of carbonate-bearing eclogite assemblages from 2.5 to $5.5 \mathrm{GPa}$ : implications for petrogenesis of carbonatites. Contrib Mineral Petrol 146:606-619

Yoshino T, Matsuzaki T, Shatskiy A, Katsura T (2009) The effect of water on the electrical conductivity of olivine aggregates and its implications for the electrical structure of the upper mantle. Earth Planet Sci Lett 288:291-300 